\title{
Pursuing the Right to an Effective Remedy for Human Rights Violation(s) In Cameroon: The Need for Legislative Reform
}

\section{AA Agbor*}

\section{P.E.R}

Pioneer in peer-reviewed, open access online law publications

Author

Avitus A Agbor

Affiliation

North-West University

South Africa

Email Avitus.Agbor@nwu.ac.za

Date published

19 December 2017

Editor Prof O Fuo

How to cite this article

Agbor AA "Pursuing the Right to an Effective Remedy for Human Rights Violation in Cameroon: The Need for Legislative Reform" PER / PELJ 2017(20) - DOI

http://dx.doi.org/10.17159/17273781/2017/v20i0a1764

\section{Copyright}

DOI

http://dx.doi.org/10.17159/17273781/2017/v20i0a1764

\begin{abstract}
Undoubtedly, global and regional human rights instruments clearly entrench the right to an effective remedy for a human rights violation. The substantive nature of the right to an effective remedy makes it relevant to the realisation of the right to equality as well as the right to equal protection under the law. Cameroon, as a State Party to most of these human rights instruments, is bound to adopt measures aimed at giving effect to the rights contained therein. One of such steps, in my opinion, is the enactment of domestic legislation that defines the content of these rights; stipulates the forums where remedies for human violations could be pursued; specifies what kinds of remedies a victim of a human rights violation would get at the end; and lastly, defines who can access such forums. Unfortunately, the lack of domestic legislation that meets these requirements means the right to an effective remedy for a human rights violation in Cameroon cannot be realised. It is argued in this paper that the critical nature of the right to a remedy, given its bearing on other substantive human rights as well as the protection and promotion of human rights, warrants progressive efforts undertaken by the State in order to give effect to this right. Therefore, the sheer lack of a legislative instrument in this regard makes it very difficult for the pursuit of a right to a remedy when there is a violation of human rights. As evidenced by legislative developments in numerous African States that are States Parties to these international instruments, there is growing consensus that the enactment of domestic legislation that answers the questions of content; forums; outcomes and access is a positive and vital step towards the realisation of the right to an effective remedy for a human rights violation.
\end{abstract}

\section{Keywords}

Right to an effective remedy; human rights litigation; democratic culture; human rights; Cameroonian legal system; South African legal system. 


\section{Introduction}

Numerous international human rights instruments recognise the right to an effective remedy for a human rights violation. ${ }^{1}$ In other words, a victim of a human rights violation is legally entitled to pursue and obtain an effective remedy. International human rights treaties provide a remedy, both substantive and procedural, for individuals suffering injury from unlawful conduct by State authorities. In addition to the right to an effective remedy for human rights violations, human rights treaties as well as some domestic constitutions, provide for specific provisions for compensation, as in the case of unlawful detention. ${ }^{2}$ The Rome Statute of the ICC authorises the Court to determine any damage, loss or injury to victims and order reparations to them. ${ }^{3}$

Domestic legal systems are yet to cope with the substance of the right to an effective remedy arising from human rights violations. Their challenges are attributable to a poor culture of accountability; refusal by the State authorities to take responsibility; the absence of legislative instruments; the fact that the judiciary is under executive control; and the costs of accessing judicial institutions if such a decision is made. As such, even when violations of human rights occur on a massive scale, there is a tendency to overlook the rights and interests of the victims. Undoubtedly, the rights and interests of victims of human rights violations are key to state responsibility, official accountability and the interests of peace and justice. As Zegveld calls it, it

Avitus A Agbor. LLB (Hons); LLM, PhD. Research Associate Professor, School of Postgraduate Studies and Research, Faculty of Law, North-West University, South Africa. Email: Avitus.Agbor@nwu.ac.za

$1 \quad$ Within the United Nations' human rights system, see, for example the following instruments: a 8 of the Universal Declaration of Human Rights (1948) (hereafter the UDHR); a 2(3)(a) of the International Covenant on Civil and Political Rights (1966) (hereafter the ICCPR); a 14(1) of the Convention against Torture and Other Cruel, Inhuman or Degrading Treatment or Punishment (1984) (hereafter CAT); a 39 of the Convention on the Rights of the Child (1989) (hereafter the CRC). Regional human rights instruments do also provide for the right to an effective remedy for human rights violations: a 13 of the European Convention for the Protection of Human Rights and Fundamental Freedoms (1950) (hereafter the European Convention); a 25(1) of the Inter-American Convention on Human Rights (1969) (hereafter the American Convention); a 7(1)(a) of the African Charter on Human and Peoples' Rights (1981) (hereafter the Banjul Charter); a 25 of the United Nations Protocol to the African Charter on Human and Peoples' Rights on the Rights of Women (2000) (hereafter Maputo Protocol).

2 See, for example, a 14(5) of the Constitution of Ghana, 1992 where it is provided that a "person who is unlawfully arrested, restricted or detained by any other person shall be entitled to compensation from that other person".

3 Article 75 of the Rome Statute of the International Criminal Court (1998) (hereafter Rome Statute of the ICC) ("Reparations to Victims"). 
constitutes "an imperative demand of justice". 4 If human rights instruments clearly stipulate the right to an effective remedy in cases of violations, then their relevance may become questionable if states' practices do not permit the realisation of this right in particular. One basic tenet of civilised legal systems is that victims of any unlawful act must have the capacity to enforce their rights before any national or international body. The absence of any such system that makes it possible for victims to exercise such a right debilitates the entire human rights system. As was pointed out by Lord Denning in the case of Gouriet $v$ Union of Post Office Workers, "a right without a remedy is no right at all". 5

The United Nations Commission on Human Rights gave recognition to the interests of victims of human rights violations by adopting the "Basic Principles and Guidelines on the Right to a Remedy and Reparations for Victims of Violations of International Human Rights and Humanitarian Law" (hereafter the Basic Principles and Guidelines). ${ }^{6}$ The aim of this instrument is to provide victims of violations (of both human rights and international humanitarian law) with a right to a remedy. ${ }^{7}$ As indicated in this document, the content of the right to a remedy for a human rights violation includes reparation for the harm suffered, ${ }^{8}$ access to justice, ${ }^{9}$ and access to factual information concerning the violations. ${ }^{10}$ The document distinguishes the different kinds of reparation: restitution, ${ }^{11}$ rehabilitation, ${ }^{12}$ compensation, ${ }^{13}$ satisfaction, ${ }^{14}$ and guarantees of non-repetition. ${ }^{15}$

The pursuit of a right to an effective remedy for a violation of human rights constitutes what is known in international legal discourse as human rights litigation. The right to pursue an effective remedy for a human rights violation is of great significance for numerous reasons: first, it is a

\author{
Zegveld 2003 IRRC 498. \\ Lord Denning in Gouriet $v$ Union of Post Office Workers [1978] AC 435 quoted by \\ Zegveld above and Higgins "Role of Domestic Courts" 38 fn 3. \\ $6 \quad$ Basic Principles and Guidelines on the Right to a Remedy and Reparations for \\ Victims of Violations of International Human Rights and Humanitarian Law (2005) \\ (hereinafter the Basic Principles and Guidelines). \\ See generally the Preamble to the Basic Principles and Guidelines. \\ Principle IX of the Basic Principles and Guidelines. \\ Principle VIII of the Basic Principles and Guidelines. \\ Principle $\mathrm{X}$ of the Basic Principles and Guidelines. \\ Guideline 19 of the Basic Principles and Guidelines. \\ Guideline 21 of the Basic Principles and Guidelines. \\ Guideline 20 of the Basic Principles and Guidelines. \\ Guideline 22 of the Basic Principles and Guidelines. \\ Guideline 23 of the Basic Principles and Guidelines.
}


substantive right like other rights contained in these instruments. ${ }^{16}$ Therefore, as spelt out in these instruments, State Parties are required to adopt various measures (including legislative and judicial) aimed at achieving the respect, protection and promotion of the rights contained therein. ${ }^{17}$ This entails, amongst other things, ensuring that a victim of a human rights violation can and should have his or her cause heard by an independent, impartial, and duly constituted court, tribunal or forum. Secondly, the right to seek redress for a human rights violation is key to the promotion and protection of human rights. In this regard, when systematic challenges make it difficult, if not impossible, for a victim of a human rights violation to seek redress in a competent forum, this becomes a worrying issue as it arouses suspicion that such a victim is not given equal recognition by the law. Neither is such a victim granted equal protection by the law. Thirdly, the right to an effective remedy has a direct bearing on every other substantive human right. This relationship is founded on the fact that these instruments recognise that every victim whose rights have been violated is legally entitled to an effective remedy by the competent national tribunals. ${ }^{18}$ In short, the justiciability of any human rights violation is directly related to the right to an effective remedy. The absence of the right to an effective remedy negates the possibility of litigating any violation of human rights. Fourthly, the uniqueness of the right to an effective remedy for a human rights violation has an important bearing on three other substantive rights: the right to recognition everywhere as a person before the law; the right to equality before the law; and the right to equal protection of the law. ${ }^{19}$ Lastly, as discussed below, the right to an effective remedy for a human rights violation, unfortunately, is a secondary right: in other words, a violation of a human right must occur before the right to a remedy can be exercised.

16 Article 8 of the UDHR; a 2(3)(a) of the ICCPR; a 6 of the CERD; a 14(1) of the CAT; a 39 of the CRC; a 13 of the European Convention; a 25 of the American Convention; a 7(1)(a) of the Banjul Charter; a 25 of the Protocol to the Banjul Charter.

17 See, for example, a 2(2) of the ICCPR obliging States Parties to "take the necessary steps, in accordance with its constitutional processes and with the provisions of the present Covenant [the ICCPR], to adopt such laws or other measures as may be necessary to give effect to the rights recognized in the present Covenant [ICCPR]"; and a 1 of the Banjul Charter, which obliges parties to the said Charter to give recognition to the rights, duties and freedoms enshrined in the Charter as well as to undertake to adopt legislative or other measures to give effect to them. Article 8 of the UDHR; a 2(3)(a) of the ICCPR; a 6 of the CERD; a 14(1) of the CAT; a 39 of the CRC; a 13 of the European Convention; a 25 of the American Convention; a 7(1)(a) of the Banjul Charter; a 25 of the Protocol to the Banjul Charter.

19 See arts 6 and 7 of the UDHR; arts 2(1), 3 and 16, respectively, of the ICCPR; and arts 3(1) and (2) of the Banjul Charter. 
There is no effective right to a remedy if a human rights violation has not occurred.

Unfortunately, and obviously, some States Parties to most of these international human rights instruments have not been able to fulfil their obligations, which, amongst other things, include the adoption of numerous measures aimed at giving effect to the rights contained therein. In other words, the substantive human rights contained in these human rights instruments as well as the obligations imposed on States Party thereto exist in ink only. Put in a practical and comparative perspective, there is a great deal of disparity in terms of how States Parties have adopted legislation and developed their judicial organs, which constitute key elements in the realisation of the right to an effective remedy for a human rights violation. In this light, Cameroon stands out as a glaring example of a State Party that has exhibited a stubborn refusal to adopt domestic measures that would give effect to the right to an effective remedy for human rights violation. The 1996 Constitution recognises some fundamental principles related to human rights and freedom, and articulates the State's commitment to the Universal Declaration of Human Rights and the African Charter on Human and Peoples' Rights. However, conspicuous flaws in this national instrument include the absence of any substantive definition of any right, the failure to articulate the right to an effective remedy, and the absence of a specified forum where victims of human rights violation could pursue a remedy. Added to these factors is the absence of specifications of who could access such a forum and what remedies such persons could expect when pursuing the right to a remedy. ${ }^{20}$ Undeniably, these factors, taken together, suggest that Cameroon is a legal black hole in the context of human rights litigation. This situation is further compounded by the unwillingness of the judiciary to construe constitutional provisions informed by human rights values and norms in order to hold perpetrators accountable. ${ }^{21}$ This has been a persistent attitude despite the fact that the Constitution makes provision for the direct applicability of ratified international instruments (including human

20 For a better understanding of this, see the 1996 Constitution of Cameroon (hereafter the Cameroon Constitution); specifically the Preamble to the Constitution, where a few principles and socio-economic and political rights are spelled out.

21

The case of The People $v$ Nya Henry (2005) AFHLR 101 (CaFI 2001) marked a change, given the boldness of the trial magistrate before whose eyes flagrant violations had been committed by an overtly arbitrary executive acting in defiance of a court order. The Legal Department (prosecutor) refused to release the detained suspects on bail even though their release had been ordered by the Court. To the Presiding Magistrate, this constituted not only a violation of the suspects' right to be presumed innocent until proved guilty but also an outright disregard of the separation of powers and independence of the judiciary with the executive branch exuding its overbearing attitude towards the judiciary. 
rights) in the country's legal system, with a superior status over domestic legislation. ${ }^{22}$ It is argued that the fact that no piece of domestic legislation stipulates the content of human rights, defines the forums that have the competence to adjudicate human rights violations, the norms that ought to be factored into such an exercise as well as access to such forums, and what remedies to expect when pursuing such a remedy militate against the pursuit of human rights litigation in Cameroon. Fortunately, numerous African States have adopted measures aimed at giving effect to the right to an effective remedy in national instruments. ${ }^{23}$ As seen below, the national constitutions of some of these States stipulate, amongst other things, the substantive content of human rights, including the right to an effective remedy. ${ }^{24}$ In addition, in order to promote and protect the rights contained therein, specific provisions are in place regarding what forums are mandated to adjudicate human rights violations, ${ }^{25}$ how such forums should construe the rights contained therein, ${ }^{26}$ who can access such forums, ${ }^{27}$ and what remedies to expect when accessing such forums for human rights violations. ${ }^{28}$ It is argued that such legal systems, especially the South African, could serve as prototypes to Cameroon, so that the right to an effective remedy exists not only in ink but is respected; promoted; and protected.

This paper examines the right to an effective remedy for violations of human rights in Cameroon. In doing so, it assesses the relevant legislative instruments and institutional mechanisms in order to find out if recognition is given to the right to an effective remedy for human rights violations, the extent to which this right is enforced, the challenges faced by victims in the exercise of this right, and what could be done to enhance the realisation of this right. Based on a perusal of the Constitution of Cameroon and the law regulating legal aid, it is argued that the 1996 Constitution does not specifically address the issue of the right to an effective remedy. Rather, it outlines a set of fundamental principles while articulating its affirmation of

22 See a 45 of the 1996 Constitution of Cameroon.

23 See, for example, the Constitution of the Republic of South Africa, 1996; the 2010 Constitution of Kenya; the 2010 Constitution of Tanzania and the 1992 Constitution of Ghana. See, for example, a 30(3)-(4) of the 2010 Constitution of Tanzania, and a 22(1) of the 2010 Constitution of Kenya.

25 See, for example, a 33(1) of the Constitution of Ghana, and a 23(1) of the Constitution of Kenya. See, for example, s 39(1) of the South African Constitution, and a 20(2) of the Constitution of Kenya.

27 See, for example, s 38 of the South African Constitution, and a 22(2) of the Constitution of Kenya. 
the contents of the UDHR and the Banjul Charter. These two instruments stipulate the right to an effective remedy for human rights violations. ${ }^{29}$ In effect, Cameroon indirectly recognises the right to an effective remedy for human rights violations. Secondly, the recognition of this right within Cameroon's legal system is derived from the direct importation and application of duly ratified international agreements which are not only law in Cameroon but also have a status superior to that of national legislation. ${ }^{30}$ Secondly, it will be argued that despite the recognition of the right to an effective remedy, significant systemic challenges in the legal system make it difficult to pursue. These challenges include the absence of an independent judiciary and the rule of law, the dearth of national forums or tribunals mandated to adjudicate on human rights violations, and the absence of a national legislation that defines the substantive content of rights easily digestible by legal practitioners. Added to these challenges is the culture of impunity, as the State evinces an unwillingness to hold its officials accountable for human rights violations. These challenges adversely impact on the right to an effective remedy, making it difficult for victims of human rights violations to pursue and succeed in realising their right to a remedy.

This paper begins with a delineation of what constitutes the right to an effective remedy for a human rights violation in international law. It then looks at the requirements for the right to an effective remedy. In other words, what must be in place for the right to an effective remedy to be realised? Thirdly, the paper scans through the 1996 Constitution of Cameroon, highlighting its glaring shortcomings and how they impact on the right to an effective remedy in Cameroon. Lastly, the paper looks at the legislative landscape of South Africa, because it is a contemporary African democracy that has transformed itself from being a racist society to a constitutional democracy built on the pillars of respect for human rights, the separation of powers, and the rule of law. As already said, some African States have made commendable strides in this regard, which are mentioned below. The purpose of this is to show how specific legislative instruments meet the necessary requirements for the pursuit of the right to an effective remedy for a human rights violation.

\footnotetext{
29 Article 8 of the UDHR; a 7(1)(a) of the Banjul Charter.

30 Article 45 of the Constitution of Cameroon.
} 


\section{The content and meaning of the right to an effective remedy for human rights violations}

Amongst the other substantive rights contained in international human rights instruments is the right to an effective remedy for the victim of a human rights violation. Couched in legal parlance as human rights litigation, roughly construed this would mean that a person who has suffered a human rights violation (direct or indirect, as explained below) is legally entitled to an effective remedy for that violation. Granting recognition to a victim's right to an effective remedy means that such a victim is given equal status before the law (the right to equality) and is accorded equal protection under the law.

The right to an effective remedy for a human rights violation is provided for in numerous international human rights instruments, both at universal and regional levels. At the universal level, the right to an effective remedy is provided for in the UDHR, ${ }^{31}$ the ICCPR, ${ }^{32}$ the CERD, ${ }^{33}$ the CAT, ${ }^{34}$ and the CRC. ${ }^{35}$ Even the Rome Statute of the ICC speaks of victims' rights to

31 Article 10 of the UDHR stipulates the right to an effective remedy for a human rights violation in the following words: "Everyone is entitled in full equality to a fair and public hearing by an independent and impartial tribunal, in the determination of his rights and obligations and of any criminal charge against him."

The right to an effective remedy is clearly stipulated in a 2(3)(a)-(c) of the ICCPR as follows: "Each State Party to the present Covenant undertakes: (a) to ensure that any person whose rights or freedoms as herein recognized are violated shall have an effective remedy, notwithstanding that the violation has been committed by persons acting in an official capacity; (b) to ensure that any person claiming such a remedy shall have his right thereto determined by competent judicial, administrative or legislative authorities, or by any other competent authority provided for by the legal system of the State, and to develop the possibilities of judicial remedy; (c) to ensure that the competent authorities shall enforce such remedies when granted." Like other rights contained in the ICCPR, every State Party to this instrument is obliged to ensure that all individuals within its territory and subject to its jurisdiction have their civil and political rights respected, including the right to effective remedy provided for in a 2(3) of the ICCPR. In addition, State Parties are obliged in accordance with their constitutional processes to take the necessary steps, including but not limited to the adoption of laws and establishment of institutions aimed at giving effect to the rights recognised in the ICCPR. Article 6 of the CERD.

34 The CAT provides for the right to an effective remedy for victims of torture in a 14(1) as follows: "Each State Party shall ensure in its legal system that the victim of an act of torture obtains redress and has an enforceable right to fair and adequate compensation, including the means for as full rehabilitation as possible. In the event of the death of the victim as a result of an act of torture, his dependants shall be entitled to compensation." 
reparations, ${ }^{36}$ urging the Court to make orders thereto. ${ }^{37}$ At regional level, this right is stipulated in the American Convention, ${ }^{38}$ the European Convention, ${ }^{39}$ and the Banjul Charter; ${ }^{40}$ as well as the Maputo Protocol thereto. ${ }^{41}$

36 Article 75 of the Rome Statute of the ICC

37 See generally a 75(1)-(5) of the Rome Statute of the ICC.

The right to an effective remedy for a human rights violation is captioned "Right to Judicial Protection" in the American Convention:

"Article 25. Right to Judicial Protection

1. Everyone has the right to simple and prompt recourse, or any other effective recourse, to a competent court or tribunal for protection against acts that violate his fundamental rights recognized by the constitution or laws of the state concerned or by this Convention, even though such violation may have been committed by persons acting in the course of their official duties.

2. The States Parties undertake:

a. to ensure that any person claiming such remedy shall have his rights determined by the competent authority provided for by the legal system of the state;

b. to develop the possibilities of judicial remedy; and

c. to ensure that the competent authorities shall enforce such remedies when granted."

The wording of a 25 of the American Convention bears some similarity with the wording of a 2(3) of the ICCPR. However, it stretches a little bit further: it guarantees the right to an effective judicial remedy to an individual whose fundamental rights have been violated not only under the American Convention but even under a domestic constitution. The case of Mayagna (Sumo) Awas Tingni Community $v$ Nicaragua illustrates how the Inter-American Court of Human Rights interprets the requirement of an effective remedy as used in a 25 of the American Convention: the Mayagna (Sumo) Awas Tingni Community v Nicaragua (hereafter the Mayagna (Sumo) Awas Tingni Community Case), Judgment, August 31, 2001, Inter-Am Ct HR, (Ser C) No 79 (2001) paras 104-139.

39 Article 13 of the European Convention stipulates the right to an effective remedy in the following words: "Everyone whose rights and freedoms as set forth in this Convention are violated shall have an effective remedy before a national authority notwithstanding that the violation has been committed by persons acting in an official capacity."

Evidently, even the European Convention recognises the right to an effective remedy where there is a violation of human rights. A 13 of the European Convention makes irrelevant the fact that the violation was committed by a person or group of persons acting in an official capacity.

40 The right to an effective remedy is stipulated in a 7(1)(a) of the Banjul Charter as follows: "Every individual shall have the right to have his cause heard. This comprises: (a) the right to an appeal to competent national organs against acts violating his fundamental rights as recognized and guaranteed by conventions, laws, regulations and customs in force."

The Banjul Charter makes mention of acts that violate the fundamental rights as "recognized and guaranteed by conventions, laws, regulations and customs in force". Per the letter of a 7(1)(a) of the Banjul Charter, the right to have a cause heard must not emanate from a violation of the Banjul Charter only. Any violation of any fundamental rights recognised and guaranteed by any instrument (whether convention, law, regulation or custom) will suffice.

The Maputo Protocol provides for the right to an effective remedy for any violation of a human right in a 25 . 


\subsection{The nature of the right to an effective remedy}

The right to an effective remedy for a human rights violation is by its very nature a secondary right. In other words, a human rights violation must occur before this right can be exercised. As a secondary right, it therefore depends on the existence of a violation (which could be past, present/continuous or threatened). The right to an effective remedy cannot be exercised if there is no actual violation (past, present or threatened). The right is related to the occurrence of violations. It therefore becomes bifurcated. First there must be a violation, which translates or transforms into the notion of a victim (defined below); and second, that violation gives rise to the pursuit of a remedy. This right can be triggered only after a human rights violation has been committed. As stated by Zegveld, the right to a remedy is a "secondary right, deriving from a primary substantive right that has been breached". ${ }^{42}$ Therefore, if there is no primary right, then there can be no secondary right. In practical terms, unless an individual's right to education, healthcare or housing has been violated, such an individual cannot seek or exercise his right to an effective remedy. The right to an effective remedy can arise if and only if a substantive right has been violated.

Secondly, the qualification that the right to an effective remedy exists only for a human rights violation also suggests that someone must have been, or will be, victimised. It therefore introduces the notion of a victim of a human rights violation. The substance of the right to an effective remedy presupposes that there is a victim whose primary right $\mathrm{s}$ (in other words, other rights) have been violated. The question that arises is this: who is considered a victim as contemplated in human rights instruments? As victims of human rights violations make up the focal point of the right to an effective remedy, it becomes imperative to delineate the concept or notion of victims used within this context. A victim of a human rights violation could be defined as someone who suffers because he or she is affected by a human rights violation. The violation in question includes but is not limited to an act of the State that infringes, without valid legal justification, on the right of the individual in question. The concept of victims may be construed to mean a single individual, a group of individuals, a segment of the population, a large community, or even an entire population that has been made to suffer because of a human rights violation. Even though this definition may seem broad and simplistic, the UN Principles assist us in understanding the concept of a victim by providing a straightforward

Zegveld 2003 IRRC 503 
definition: victims are "persons who individually or collectively suffered harm, including physical or mental injury, emotional suffering, economic loss or substantial impairment of their fundamental rights, through acts or omissions that constitute gross violations of international human rights law or serious violations of international humanitarian law".

The term "victim" is also construed in a much broader sense to include "the immediate family or dependants of the direct victim and persons who have suffered harm in intervening to assist victims in distress or to prevent victimisation". ${ }^{43}$

As stipulated in the Resolution, a person shall be considered a victim irrespective of whether the perpetrator of the act or omission constituting a violation has been identified, apprehended, prosecuted, or convicted as well as regardless of any relationship the perpetrator may have with the victim. ${ }^{44}$

\subsection{The meaning of an "effective remedy"}

The reticence of these instruments in defining or characterizing what constitutes a remedy for violations of human rights warrants an exploration of the literature on this in order to develop a proper grasp of what it is. In this regard, the Human Rights Committee's (hereafter HRC) General Comments and the UN Basic Guidelines are invaluable.

To begin with, the HRC has spelt out what constitutes the right to an effective remedy as stipulated in article 2(3)(a)-(c) of the ICCPR. According to the HRC, article 2(3)(a)-(c) of the ICCPR

... makes it clear that victims of violations of human rights are entitled to an effective remedy. The exercise of this right to an effective remedy must be determined by competent judicial, administrative or legislative authorities. In the absence of these, such a determination can be made by any other competent authority put in place by the State's legal system. States in such a category are urged to 'develop the possibilities of judicial remedy'. Lastly, where such an effective remedy is secured, the State is obliged to ensure that competent authorities enforce such remedies.

Elaborating on the substantive content of the right to an effective remedy as stipulated in the ICCPR, the HRC has construed this as follows:

Article 2, paragraph 3 , requires that in addition to effective protection of Covenant rights States Parties must ensure that individuals also have accessible and effective remedies to vindicate those rights. Such remedies should be appropriately adapted so as to take account of the special

43 Principle V, Guideline 8 of the Basic Principles and Guidelines.

44 Principle V, Guideline 9 of the Basic Principles and Guidelines. 
vulnerability of certain categories of person, including in particular children. The Committee attaches importance to States Parties' establishing appropriate judicial and administrative mechanisms for addressing claims of rights violations under domestic law. The Committee notes that the enjoyment of the rights recognized under the Covenant can be effectively assured by the judiciary in many different ways, including direct applicability of the Covenant, application of comparable constitutional or other provisions of law, or the interpretive effect of the Covenant in the application of national law. Administrative mechanisms are particularly required to give effect to the general obligation to investigate allegations of violations promptly, thoroughly and effectively through independent and impartial bodies. National human rights institutions, endowed with appropriate powers, can contribute to this end. A failure by a State Party to investigate allegations of violations could in and of itself give rise to a separate breach of the Covenant. Cessation of an ongoing violation is an essential element of the right to an effective remedy.

...Article 2, paragraph 3, requires that States Parties make reparation to individuals whose Covenant rights have been violated. Without reparation to individuals whose Covenant rights have been violated, the obligation to provide an effective remedy, which is central to the efficacy of article 2, paragraph 3 , is not discharged. In addition to the explicit reparation required by articles 9 , paragraph 5 , and 14 , paragraph 6 , the Committee considers that the Covenant generally entails appropriate compensation. The Committee notes that, where appropriate, reparation can involve restitution, rehabilitation and measures of satisfaction, such as public apologies, public memorials, guarantees of non-repetition and changes in relevant laws and practices, as well as bringing to justice the perpetrators of human rights violations. ${ }^{45}$

The Basic Principles and Guidelines offers some specifics on the right to an effective remedy in the fields of international human rights law and international humanitarian law. Since this discussion takes place within the context of violations of human rights, specific references will be made to this issue only, leaving out the dimension of international humanitarian law. As spelled out, some of its aims are to "identify mechanisms, modalities, procedures and methods for the implementation of existing legal obligations under international human rights law and international humanitarian law...."46 Outlining the scope of obligations contained in the Basic Principles and Guidelines, mention is made of the "obligation to respect, ensure respect for and implement international human rights law and IHL as provided for under the respective bodies of law". This includes, amongst other things, the duty to "provide those who claim to be victims of a human rights or humanitarian law violation with equal and effective access to justice... irrespective of who may ultimately be the bearer of responsibility for the violation; and provide effective remedies to victims, including reparation...."47

45 United Nations Human Rights Committee Nature of the General Legal Obligation on States Parties to the Covenant (2004).

$46 \quad$ Preamble to the Basic Principles and Guidelines.

47 Principle I, Guideline 1, Basic Principles and Guidelines. 
Based on this international instrument as well as the works of academics, ${ }^{48}$ it could be said that the right to an effective remedy comprises three important parts: the procedural dimension of the right; the substantive aspect of the right such as the outcome that the victim gets; and lastly, access to relevant information regarding the exercise of this right. ${ }^{49}$

\title{
2.2.1 Access to justice as a procedural aspect of the right to an effective remedy
}

The procedural aspect of the right to an effective remedy demands that the remedy or remedies in question must be accessible by such victims. The UN Guidelines outline what access means in this context in the following words:

\begin{abstract}
A victim of a gross violation of international human rights law... shall have equal access to an effective judicial remedy as provided for under international law. Other remedies available to the victim include access to administrative and other bodies, as well as mechanisms, modalities and proceedings conducted in accordance with domestic law. Obligations arising under international law to secure the right to access justice and fair and impartial proceedings shall be reflected in domestic laws. ${ }^{50}$
\end{abstract}

In fulfilling this obligation to provide equal access to justice, Principle VIII of the Basic Principles and Guidelines outlines a set of guidelines for States:

(a) Disseminate, through public and private mechanisms, information about all available remedies for gross violations of international human rights law...

(b) Take measures to minimize the inconvenience to victims and their representatives, protect against unlawful interference with their privacy as appropriate and ensure their safety from intimidation and retaliation, as well as that of their families and witnesses, before, during and after judicial, administrative, or other proceedings that affect the interests of victims;

(c) Provide proper assistance to victims seeking access to justice;

(d) Make available all appropriate legal, diplomatic and consular means to ensure that victims can exercise their rights to remedy for gross violations of international human rights law or serious violations of international humanitarian law. ${ }^{51}$

Regarding individual access to justice, the States are urged to take steps to "develop procedures to allow groups of victims to present claims for

\footnotetext{
$48 \quad$ For example, see Shelton Remedies in International Human Rights Law.

49 See Principles VIII, IX and X of the Basic Principles and Guidelines.

$50 \quad$ Principle 12 of the Basic Principles and Guidelines.

51 Guideline 12(a)-(d) of the Basic Principles and Guidelines.
} 
reparation and to receive reparation, as appropriate". ${ }^{52}$ A procedural right to an effective remedy, per the Principles, includes "all available and appropriate international processes in which a person may have legal standing and should be without prejudice to any other domestic remedies". ${ }^{53}$

\title{
2.2.2 Substantive content of the right to an effective remedy: the outcome(s)
}

The second aspect of the right to an effective remedy is the outcome that a victim is expected to get, based on the violation that he, she or they suffered. Core to this outcome are reparations, whose purpose and nature are outlined in the UN Guidelines:

\begin{abstract}
Adequate, effective and prompt reparation is intended to promote justice by redressing gross violations of international human rights law.... Reparation should be proportional to the gravity of the violations and the harm suffered. In accordance with its domestic laws and international legal obligations, a State shall provide reparation to victims for acts or omissions which can be attributed to the State and constitute gross violations of international human rights law... In cases where a person, a legal person, or other entity is found liable for reparation to a victim, such party should provide reparation to the victim or compensate the State if the State has already provided reparation to the victim. ${ }^{54}$
\end{abstract}

These Principles further urge States to "establish national programmes for reparation and other assistance to victims in the event that the parties liable for the harm suffered are unable or unwilling to meet their obligations". In addition, with regards to claims by victims, States are required to

... enforce domestic judgments for reparation against individuals or entities liable for the harm suffered and endeavour to enforce valid foreign legal judgments for reparation in accordance with domestic law and international legal obligations. To that end, States should provide under their domestic laws effective mechanisms for the enforcement of reparation judgments.

The Basic Principles and Guidelines delineate the concept of reparations as an effective remedy for violations of human rights. Reparations may take

\footnotetext{
52 Guideline 13 of the Basic Principles and Guidelines.

53 Guideline 14 of the Basic Principles and Guidelines.

54 Guideline 15 of the Basic Principles and Guidelines.
} 
diverse forms, which include restitution, ${ }^{55}$ compensation, ${ }^{56}$ rehabilitation, ${ }^{57}$ satisfaction, ${ }^{58}$ and guarantees of non-repetition. ${ }^{59}$

Guideline 19 of the Basic Principles and Guidelines outlines the content of restitution as a form of reparations: "Restitution should, whenever possible, restore the victim to the original situation before the gross violations of international human rights law or serious violations of international humanitarian law occurred. Restitution includes, as appropriate: restoration of liberty, enjoyment of human rights, identity, family life and citizenship, return to one's place of residence, restoration of employment and return of property."

"Compensation should be provided for any economically assessable damage, as appropriate and proportional to the gravity of the violation and the circumstances of each case, resulting from gross violations of international human rights law and serious violations of international humanitarian law, such as physical or mental harm; lost opportunities, including employment, education and social benefits; material damages and loss of earnings, including loss of earning potential; moral damage; and costs required for legal or expert assistance, medicine and medical services, and psychological and social services": Guideline 20(a)-(e) of the Basic Principles and Guidelines. According to Guideline 21 of the Basic Principles and Guidelines, rehabilitation "should include medical and psychological care as well as legal and social services." Satisfaction as reparation may take diverse forms, and may include some or all of the following:

"(a) Effective measures aimed at the cessation of continuing violations;

(b) Verification of the facts and full and public disclosure of the truth to the extent that such disclosure does not cause further harm or threaten the safety and interests of the victim, the victim's relatives, witnesses, or persons who have intervened to assist the victim or prevent the occurrence of further violations;

(c) The search for the whereabouts of the disappeared, for the identities of the children abducted, and for the bodies of those killed, and assistance in the recovery, identification and reburial of the bodies in accordance with the expressed or presumed wish of the victims, or the cultural practices of the families and communities;

(d) An official declaration or a judicial decision restoring the dignity, the reputation and the rights of the victim and of persons closely connected with the victim;

(e) Public apology, including acknowledgement of the facts and acceptance of responsibility;

(f) Judicial and administrative sanctions against persons liable for the violations;

(g) Commemorations and tributes to the victims;

(h) Inclusion of an accurate account of the violations that occurred in international human rights law and international humanitarian law training and in educational material at all levels."

Guideline 22(a)-(h) of the Basic Principles and Guidelines.

59 According to Guideline 23 of the Basic Principles and Guidelines, guarantees of nonrepetition include measures aimed at preventing non-repetition of the violation. These include:

"(a) Ensuring effective civilian control of military and security forces;

(b) Ensuring that all civilian and military proceedings abide by international standards of due process, fairness and impartiality;

(c) Strengthening the independence of the judiciary;

(d) Protecting persons in the legal, medical and health-care professions, the media and other related professions, and human rights defenders; 


\subsubsection{The right to information}

As spelt out in the Basic Principles and Guidelines, the right to an effective remedy for human rights violations also entails a right to information. This requires States to make available to victims of human rights violations "legal, medical, psychological, social, administrative and all other services". ${ }^{60}$ In addition, victims as well as their representatives should be entitled to seek and obtain information on the causes leading to their victimization and on the causes and conditions pertaining to the gross violations of international human rights law and serious violations of international humanitarian law and to learn the truth in regard to these violations. ${ }^{61}$

As explained above, the right to an effective remedy has both a procedural and a substantive dimension. The Comments of the UN Human Rights Committee as well as the UN Basic Principles and Guidelines, which urge states to take certain steps to ensure the realisation of this right, highlight the need for legislative reforms that incorporate this right into their domestic legal system, the forum for victims to access, the remedies to be spelt out, and who can actually access such forums.

\section{Pursuing human rights litigation in Cameroon: A snapshot of the legal system}

Cameroon's legal system provides for the direct importation of duly ratified international instruments. These instruments, as stipulated in the Constitution, have a status superior to that of national legislation. Therefore, it could be said that international law constitutes not only a source of law in Cameroon, but also trumps domestic laws. Cameroon is a State Party to numerous international human rights instruments, some of which include the ICCPR, the International Covenant on Economic, Social and Cultural

(e) Providing, on a priority and continued basis, human rights and international humanitarian law education to all sectors of society and training for law enforcement officials as well as military and security forces;

(f) Promoting the observance of codes of conduct and ethical norms, in particular international standards, by public servants, including law enforcement, correctional, media, medical, psychological, social service and military personnel, as well as by economic enterprises;

$(g)$ Promoting mechanisms for preventing and monitoring social conflicts and their resolution;

(h) Reviewing and reforming laws contributing to or allowing gross violations of international human rights law and serious violations of international humanitarian law."

$60 \quad$ Guideline 24 of the Basic Principles and Guidelines.

61 Guideline 24 of the Basic Principles and Guidelines. 
Rights (hereafter the ICESCR), the Convention against Torture, the CEDAW, and the Banjul Charter. As said earlier, most of these instruments spell out obligations that have to be fulfilled by the States Parties in order to enhance the respect, protection and promotion of the rights contained therein. Some of these measures include the adoption and enactment of national legislative instruments that give effect to the rights in question. For example, the Banjul Charter urges States Party thereto to "recognise the rights, duties and freedoms enshrined" therein and to "adopt legislative or other measures to give effect to them." 62 In addition to this obligation, States Party to the Banjul Charter have a solemn duty to "guarantee the independence of the courts" and also to "allow the establishment and improvement of appropriate national institutions entrusted with the promotion and protection of the rights and freedoms" spelt out in the Banjul Charter. ${ }^{63}$ Upon ratification of these instruments, Cameroon assumed full responsibility to fulfil these obligations in order to ensure the respect, promotion and protection of the rights contained in these instruments. The question that arises is this: has Cameroon adopted legislative measures and institutional mechanisms aimed at realising the right to a remedy for violations of human rights? The answer to this question can be found by looking at the substantive content of human rights as stipulated in the 1996 Constitution.

\subsection{The 1996 Constitution: An utter disappointment?}

A perusal of the Constitution of Cameroon reveals that there is no direct substantive inclusion of human rights therein. The legislative content is not only inadequate but very wanting in terms of the definition of substantive human rights. Therefore, as a starting point, the 1996 Constitution fails to give a meaningful and substantive definition of what constitutes human rights, especially what is borrowed from international instruments. Affirmation is made to the UDHR and the Banjul Charter, with a regurgitation of some "principles" that are inserted into the Preamble. No provision is made on the right to an effective remedy. It seems that this is not a key principle that underlies human rights in Cameroon. Or better stated, Cameroon's legal system does not accommodate the exercise of the right to an effective remedy. However, the provisions of the Banjul Charter do recognise the right to an effective remedy, and as such, Cameroon as a

\footnotetext{
62 Article 1 of the Banjul Charter.

63 Article 26 of the Banjul Charter.
} 
State Party thereto ought to adopt measures aimed at ensuring the realisation of this right.

Furthermore, relevant to the pursuit of the right to a remedy is a forum. In cases where a victim's rights have been violated, which forum is available for such a victim to seek a remedy? Is it the ordinary or special courts of the land? Is this power allocated to administrative courts? The absence of a provision that defines the forum itself complicates the issue of pursuing the right to an effective remedy.

Added to these challenges is the question of how such forums should construe rights. In adjudicating on any right, as well as the right to pursue a remedy, the 1996 Constitution also fails to define what guidelines ought to be used in interpreting the rights.

Lastly, the question of access to the forums is unaddressed. Given all these fundamental shortcomings, it could be argued that Cameroon has not made any significant progress towards promoting and protecting the right to an effective remedy for human rights violations. Substantive deficiencies and significant flaws in its legal system greatly impede the realisation of the right to an effective remedy. In practice, this hampers any attempt to obtain a remedy for a human rights violation. It is therefore suggested that Cameroon should consider amending its 1996 Constitution in order to effect substantive changes that enhance the realisation of human rights litigation. These changes, it is recommended, should repair the flaws that are inherent in the 1996 Constitution, especially the issue of the substantive definition of human rights; the forums that are mandated to deal with violations of human rights; access to such forums; the remedies to expect at the end of the litigation; and what norms should guide the construction of rights contained in this legislation. In crafting such provisions, it is recommended that Cameroon should consider the experiences of some other African States, specifically Ghana, Benin, Kenya, Tanzania and the Republic of South Africa.

\section{The pursuit of human rights litigation: Borrowing from other African experiences}

As stated earlier, numerous African States have taken steps to domesticate the contents of international human rights instruments. Through legislative reforms, especially with regard to their national constitutions, the substantive content of human rights has been defined. More importantly, these revised constitutions also address issues such as the right to an 
effective remedy for a violation of any of the rights contained therein; the forums where such a right to an effective remedy can be pursued; the substantive remedies available to victims; the categories of persons who can enforce rights in such forums; and lastly, guidelines on how to interpret the substantive content of these rights. In this light, the constitutions of Ghana, Kenya, Tanzania and South Africa are worth considering. Gauged against one another, these constitutions have particular strengths and weaknesses, but it is argued that instead of reinventing a wheel, the Cameroonian legal system could learn from these foreign national instruments and generate a legislative text that meets all requirements for the pursuit of a right to an effective remedy for human rights violations.

\subsection{The legislative expression of human rights: Lessons from selected African countries}

Numerous African countries have taken giant steps in domesticating the right to an effective remedy by entrenching it in their national constitutions. In addition, they have addressed the procedural aspect of the right to a remedy (access to justice) in such national legislation. The constitutions of South Africa, Ghana, Kenya and Tanzania, to mention a few, are examples that could serve as models for the Cameroonian legal system on the necessary steps to adopt in order to give effect to the right to an effective remedy for human rights violations. As a starting point, the legislative expression of human rights in South Africa's legal system is made in the 1996 Constitution. 64 In the Preamble to the Constitution, there is a commitment to "heal the divisions of the past and establish a society based on democratic values, social justice and fundamental human rights", while Chapter One of the Constitution articulates the fundamental values of the South African Constitution, some of which include the following: "human dignity, the achievement of equality and the advancement of human rights and freedoms";65 "non-racialism and non-sexism";66 and the "supremacy of the Constitution and the rule of law". ${ }^{67}$ Section 2 of the Constitution articulates the supremacy of the Constitution, and declares that law or conduct that is inconsistent with it is invalid, with an emphasis on the provision that the obligations imposed by the Constitution must be fulfilled. Chapter Two of the Constitution is entitled "Bill of Rights". It contains the core civil and political rights in South Africa's legal system. However, prior

\footnotetext{
64 Chapter 2 of the South African Constitution ("Bill of Rights").

65 Section 1(a) of the South African Constitution.

66 Section 1 (b) of the South African Constitution.

67 Section 1(c) of the South African Constitution.
} 
to defining what these rights are, Section 7 defines the precise role of human rights in South Africa's democracy:

(1) This Bill of Rights is a cornerstone of democracy in South Africa. It enshrines the rights of all people in our country and affirms the democratic values of human dignity, equality and freedom.

(2) The state must respect, protect, promote and fulfil the rights in the Bill of Rights.

The South African Bill of Rights binds all state organs: the executive, the legislature and the judiciary. ${ }^{68}$ The Bill of Rights recognises and defines the substance of the rights to equality; ${ }^{69}$ human dignity; ${ }^{70}$ life $;{ }^{71}$ freedom and security of the person;72 freedom from slavery, servitude and forced labour; ${ }^{73}$ privacy $;{ }^{74}$ freedom of religion, belief and opinion; ${ }^{75}$ freedom of expression; ${ }^{76}$ assembly, demonstration, picket and petition; ${ }^{77}$ freedom of association; 78 political participation; 79 freedom of movement and residence; 80 freedom of trade, occupation and profession;81 fair labour practices $; 82$ environment; ${ }^{83}$ property; ${ }^{84}$ housing $; 85$ healthcare, food, water and social security; ${ }^{86}$ education; 87 language and culture; 88 access to information; ${ }^{89}$ just administrative action; 90 and due process. ${ }^{91}$ In addition to the rights contained in the Bill of Rights, municipal pieces of legislation have been enacted to govern specific issues related to some of the rights listed above. $^{92}$ The legislative expression of the core human rights (civil, political,

\footnotetext{
68 Section 8(1) of the South African Constitution.

69 Section 9 of the South African Constitution.

70 Section 10 of the South African Constitution.

71 Section 11 of the South African Constitution.

72 Section 12 of the South African Constitution.

73 Section 13 of the South African Constitution.

74 Section 14 of the South African Constitution.

75 Section 15 of the South African Constitution.

76 Section 16 of the South African Constitution.

77 Section 17 of the South African Constitution.

78 Section 18 of the South African Constitution.

79 Section 19 of the South African Constitution.

80 Section 21 of the South African Constitution.

81 Section 22 of the South African Constitution.

82 Section 23 of the South African Constitution.

83 Section 24 of the South African Constitution.

84 Section 25 of the South African Constitution.

85 Section 26 of the South African Constitution.

86 Section 27 of the South African Constitution.

87 Section 29 of the South African Constitution.

88 Section 30 of the South African Constitution.

89 Section 32 of the South African Constitution.

90 Section 33 of the South African Constitution.

91 Sections 34-35 of the South African Constitution.

92 For example, the Promotion of Administrative Justice Act 3 of 2000 was enacted to give effect to the right to just administrative action as spelt out in $s 33$ of the
} 
economic, social and cultural) is found in the current national constitutions of Ghana;93 Kenya; 94 and Tanzania. ${ }^{95}$

Gauged against the national constitutions of South Africa, Ghana, Kenya and Tanzania, the shortcomings of the Cameroonian Constitution become very conspicuous, as it does not address human rights in detail. Even though constitutional recognition is given to some democratic ideals, such as human rights, ${ }^{96}$ the content of human rights in Cameroon's legal system can be adduced only through the importation of international instruments that have been ratified as spelled out in Article 46 of the Constitution. It is therefore argued that in taking steps to give effect to the right to an effective remedy for human rights violations, the Cameroonian legal system could, as a major step, consider the approaches taken by some other African countries, domesticating these rights by entrenching them in a national piece of legislation such as the Constitution. The national constitutions of South Africa, Ghana, Kenya and Tanzania, in addition to spelling out substantive rights, further articulate the right to an effective remedy in cases of human rights violations.

\subsection{The forum}

In addition to the legislative expression of human rights in general and the right to an effective remedy in particular, a legal system must provide the forum for the exercise of the right to an effective remedy. As discussed earlier, the right to an effective remedy is a secondary right, meaning that a violation of a substantive human right must occur for it to be triggered. The procedural dimension of the right to an effective remedy requires the establishment of judicial and administrative mechanisms aimed at ensuring that victims can exercise their right to an effective remedy. In this regard, a national legislation must clearly spell out the forums where such remedies can be pursued. The Ghanaian Constitution, in addition to defining human rights, stipulates means for their protection as follows in article 33:

(1) Where a person alleges that a provision of this Constitution on the fundamental human rights and freedoms has been, or is being or is

Constitution; the Promotion of Access to Information Act 2 of 2000 which gives effect to the right to access to information as required under s 32(2) of the Constitution. See generally, Currie Promotion of Administrative Justice Act; Hoexter Administrative Law.

The 1992 Constitution of Ghana, Ch 5 ("Fundamental Human Rights and Freedoms"), arts 12-33. Articles 19-57 of the Constitution of Kenya, Ch 4("Bill of Rights"). Articles 12-30 of the Constitution of Tanzania, Part III ("Basic Rights and Duties"). Article 1(2) of the South African Constitution. 
likely to be contravened in relation to him, then, without prejudice to any other action that is lawfully available, that person may apply to the High Court for redress.

(2) The High Court may, under clause (1) of this article, issue such directions or orders or writs including rites or orders in the nature of herbs as corpus, certiorari, mandamus, prohibition, and quo warrant as it may consider appropriate for the purposes of enforcing or securing the enforcement of any of the provisions on the fundamental human rights and freedoms to the protection of which the person concerned is entitled.

(3) A person aggrieved by a determination of the High Court may appeal to the Court of Appeal with the right of a further appeal to the Supreme Court.

(4) The Rules of Court Committee may make rules of court with respect to the practice and procedure of the Superior Courts for the purposes of this article.

(5) The rights, duties, declarations and guarantees relating to the fundamental human rights and freedoms specifically mentioned in this Chapter shall not be regarded as excluding others not specifically mentioned which are considered to be inherent in a democracy and intended to secure the freedom and dignity of man.

As seen above, the High Courts of Ghana are constitutionally mandated to act as the protection mechanism of human rights in Ghana. Also, in Kenya the High Court is mandated with the authority to uphold and enforce the Bill of Rights in the Constitution. ${ }^{97}$ The Constitution of Tanzania also accords jurisdiction to the High Court over matters pertaining to violations of the human rights contained therein. ${ }^{98}$

In addition to defining the competent forums, these legal systems also empower specific categories of persons to enforce these rights in these forums: for example, article 22(2) of the Kenyan Constitution, ${ }^{99}$ or section

97 Article 23(1) of the 2010 Constitution of Kenya: "The High Court has jurisdiction...to hear and determine applications for redress of a denial, violation or infringement of, or threat to, a right or fundamental freedom in the Bill of Rights."

Article 30(3)-(4) of the Tanzania Constitution:

"(3) Any person claiming that any provision in this Part of this Chapter or in any law concerning his right or duty owed to him has been, is being or is likely to be violated by any person anywhere in the United Republic, may institute proceedings for redress in the High Court.

(4) Subject to the other provisions of this Constitution, the High Court shall have original jurisdiction to hear and determine any matter brought before it pursuant to this Article; and the state authority may enact legislation for the purposes of...."

"(2) In addition to a person acting in their own interest, court proceedings under clause (1) may be instituted by-

(a) a person acting on behalf of another person who cannot act in their own name;

(b) a person acting as a member of, or in the interest of, a group or class of persons;

(c) a person acting in the public interest; or

(d) an association acting in the interest of one or more of its members." 


\section{8 of the South African Constitution. ${ }^{100}$}

Clearly, the Constitution of Cameroon neither stipulates what forums victims of human rights violations could approach for a remedy, nor does it define what persons are empowered to enforce these rights. It is therefore recommended in developing a national piece of legislation that grants recognition to human rights that such legislation must define the forum as well as identify those who can enforce those rights. The South African and Kenyan legal systems are templates worthy of consideration. When legal systems prescribe technical rules on standing, requiring only the direct or indirect victims to have the capacity or standing to initiate litigation in a forum, then that becomes very restrictive, and ultimately may have an adverse effect on some victims, especially those who are mired in socioeconomic hardships. In this regard the South African and Kenyan constitutions relax the rules on standing by making it possible for various categories of persons to be able to see to the enforcement of the rights of individuals. ${ }^{101}$ This approach, it is suggested, should be adopted by Cameroon's legal system. The essence of this is to enhance the pursuit of human rights litigation, especially by victims who, for socio-economic reasons or because of other hardships, may encounter challenges. By granting numerous persons the right to litigate or enforce the rights of others, the access to the forums becomes much easier and wider, and accountability is not retarded by technical rules of procedure which often end up being counter-productive.

\subsection{The interpretation of rights}

Both the South African and the Cameroonian constitutions mandate the

100 Section 38 of the South African Constitution: "Enforcement of rights

Anyone listed in this section has the right to approach a competent court, alleging that a right in the Bill of Rights has been infringed or threatened, and the court may grant appropriate relief, including a declaration of rights. The persons who may approach a court are -

(a) anyone acting in their own interest;

(b) anyone acting on behalf of another person who cannot act in their own name;

(c) anyone acting as a member of, or in the interest of, a group or class of persons;

(d) anyone acting in the public interest; and

(e) an association acting in the interest of its members."

101 Section 38 of the South African Constitution is captioned "Enforcement of rights", and entitles the following persons to approach a competent court, alleging that a right in the Bill of Rights has been infringed or threatened, and praying the court to grant appropriate relief: anyone acting in their own interest; anyone acting on behalf of another person who cannot act in their own name; anyone acting as a member of, or in the interest of, a group or class of persons; anyone acting in the public interest; and an association acting in the interest of its members. 
judiciary as the organ charged with the interpretation and application of laws in their respective legal systems. Also, both systems have given legislative expression of what constitutes human rights, even though in very different ways and to a very different extent. However, like any legislative text that requires interpretation, the courts are guided by technical rules of statutory interpretation. Given the sanctity of human rights in South Africa's constitutional democracy and the need to build and develop a culture of human rights and accountability, and in an attempt to ensure the equality of all before the law, the Constitution further articulates rules that should be applied by the different forums in interpreting any of the provisions of the Bill of Rights. In doing so, the lawmaker provides the adjudicators with the relevant tools that are needed in this arduous and delicate task. First, such a court, tribunal or forum "must promote the values that underlie an open and democratic society based on human dignity, equality and freedom". Second, such a forum is obliged to consider the spirit and letter of international law. Third, such a forum is at liberty to consider foreign law. Article 39(2) of the Constitution prescribes the desired spirit that should underlie the interpretation of the Bill of Rights. ${ }^{102}$ On interpreting the rights that are contained in the Constitution of Cameroon, as well as those in international instruments that have been ratified by Cameroon, the judiciary as well as every other mandated organ must not be guided only by the canons of statutory construction. Neither should they be limited to their "conscience and the law", or be motivated by their allegiance to a political entity, an individual or a group of persons. The interpretation of the rights is key to giving enforcement to them. As such, adjudicators must give expression to the rights by looking at the right itself as spelt out in the national legislation and construed by international bodies; should consider how other legal systems have approached them; and lastly, should be guided by the core and fundamental principles of a democratic society.

\subsection{The remedies}

A substantial component of the right to an effective remedy for a human rights violation is that the victim must be able to get a remedy from whatever forum is mandated to adjudicate such disputes. The Basic Principles and Guidelines stipulates the substantive content of remedies for human rights violations. Reparations, which are at the core of remedies, could be compensation, restitution, satisfaction, rehabilitation, and guarantees of

102 Section 39(2) of the South African Constitution provides as follows: "When interpreting any legislation, and when developing the common law or customary law, every court, tribunal or forum must promote the spirit, purport and objects of the Bill of Rights." 
non-repetition. The Kenyan Constitution contemplates the kinds of remedies that could be awarded by the High Court to a victim of a human rights violation in Article 23(3) as follows:

In any proceedings brought under Article 22 [Enforcement of Bill of Rights], a court may grant appropriate relief, including-
(a) a declaration of rights;
(b) an injunction;
(c) a conservatory order;
(d) a declaration of invalidity of any law that denies, violates, infringes, or threatens a right or fundamental freedom in the Bill of Rights and is not justified under Article 24;
(e) an order for compensation; and
(f) an order of judicial review.

\title{
5 Conclusion
}

For the most part, international human rights instruments spell out the substantive content of human rights: civil, political, economic, social and cultural rights. This is evidenced by the inclusion of provisions to this effect in international human rights instruments. As one scholar observed,

\begin{abstract}
International human rights can only be effective on the ground, where they really matter, if national courts, parliaments, and governments rely on them, and if civil society mobilizes in order to hold authorities accountable on that basis. ${ }^{103}$
\end{abstract}

States as the principal subjects of international law enter into bilateral and multilateral agreements. Some of these agreements relate to trade, migration, technological development, etc. Unfortunately, international human rights treaties are uniquely distinct from most other international agreements or instruments. The conclusion of such agreements is not for the interest of the parties but for the benefit of the population in the party's jurisdiction at any given time. In this regard, Louis Henkin remarked that, in effect, this implies that "the principal element of horizontal deterrence is missing - the threat that 'if you violate the human rights of your inhabitants, we will violate the human rights of our inhabitants' hardly serves as a deterrent". ${ }^{104}$ According to Hathaway,

... a nation's actions against its own citizens do not directly threaten or harm other states. Human rights law thus stands out as an area of international law

\footnotetext{
103 De Schutter International Human Rights Law 729. See also Beyleveld 1995 Public Law 577; Heyns and Viljoen Impact of the United Nations Human Rights Treaties; Schachter "Obligation to Implement the Covenant". For additional reading on the role of national courts in applying international human rights, see Conforti and Francioni Enforcing International Human Rights. 
in which countries have little incentive to police non-compliance with treaties or norms. ${ }^{105}$

This troubling reality of the nature and dynamics of international politics is further worsened by the fact the principle of sovereignty of a state bars any foreign entity from interfering with the internal affairs of another state. Consequently, as Hathaway believes, the ratification of an international human rights treaty simply serves as a symbolic or expressive gesture. It merely sends a message to the global community at large that the ratifying state wishes to be seen as a worthy and trusted partner with regards to addressing the issues contained in such an instrument. The ratification by a state of an international human rights treaty does not make a significant positive difference in the lives of the people over which it has jurisdiction. If this holds true, then the domestication of international human rights instruments may be seen as worthier effort by a State to give effect to these instruments, and could also ensure compliance through national institutions.

With the inclusion of the right to an effective remedy for violations of human rights, States Parties are required to adopt numerous measures aimed at enhancing the respect, protection and promotion of human rights. As explained earlier, the nature of the obligations imposed upon States Parties, when viewed broadly, require that they must take steps to end practices and norms that facilitate in any way the commission of violations on the one hand, and designate and adopt measures aimed at fostering a culture of accountability. The adoption of measures without suppressing practices and norms that foster the commission of violations is counter-productive. Therefore, it is hoped that the Cameroonian legal system will be reformed to incorporate the two-dimensional obligation contained in international human rights instruments and described above in order to give effect to the right to an effective remedy as stipulated therein. Legislative reforms that meet the requirements discussed above constitute just one dimension. The suppression of norms and practices that constitute or facilitate the commission of human rights violations should be complemented by legislative reforms aimed not only at giving effect to the right to an effective remedy but also at developing a culture of norms and practices that would bolster respect for human rights.

105 Hathaway 2002 Yale LJ 1938. 


\section{Bibliography}

\section{Literature}

Beyleveld 1995 Public Law

Beyleveld D "Convention on Human Rights" 1995 Public Law 577-598

Comforti and Francioni Enforcing International Human Rights

Conforti B and Francioni F (eds) Enforcing International Human Rights in Domestic Courts (Boston Martinus Nijhoff 1997)

Currie Promotion of Administrative Justice Act

Currie I The Promotion of Administrative Justice Act: A Commentary $2^{\text {nd }}$ ed (Siber Ink Cape Town 2007)

De Schutter International Human Rights Law

De Schutter O International Human Rights Law (Cambridge University Press Boston 2010)

Hathaway 2002 Yale LJ

Hathaway O "Do Human Rights Treaties Make a Difference?" 2002 Yale LJ 1935-2042

Henkin International Law

Henkin L International Law: Politics, Values and Functions (Martinus Nihoff The Hague 1989)

Heyns and Viljoen Impact of the United Nations Human Rights Treaties Heyns C and Viljoen F The Impact of the United Nations Human Rights Treaties on the Domestic Level (Kluwer Law International The Hague 2002)

Higgins "Role of Domestic Courts"

Higgins R "The Role of Domestic Courts in the Enforcement of International Human Rights: The United Kingdom" in Conforti B and Francioni F (eds) Enforcing International Human Rights in Domestic Courts (Boston Martinus Nijhoff 1997) 37-58

Hoexter Administrative Law

Hoexter C Administrative Law in South Africa $2^{\text {nd }}$ ed (Juta Cape Town 2012)

Schachter "Obligation to Implement the Covenant"

Schachter O "The Obligation to Implement the Covenant in Domestic Law" in Henkin L (ed) The International Bill of Rights: The Covenant on Civil and Political Rights (Columbia University Press Columbia 1981) 311-331 
Shelton Remedies in International Human Rights Law

Shelton DL Remedies in International Human Rights Law $2^{\text {nd }}$ ed (Oxford University Press Oxford 2005)

Zegveld 2003 IRRC

Zegveld $L$ "Remedies for Victims of Violations of International Humanitarian Law" 2003 IRRC 497-526

\section{Case law}

Gouriet v Union of Post Office Workers [1978] AC 435

Mayagna (Sumo) Awas Tingni Community v Nicaragua Judgment, August 31, 2001 Inter-Am Ct HR, (Se. C) No 79 (2001)

The People v Nya Henry (2005) AFHRL 101 (CaFI 2001)

\section{Legislation}

Constitution of Cameroon, 1996

Constitution of Ghana, 1992

Constitution of Kenya, 2010

Constitution of Tanzania, 2010

Constitution of the Republic of South Africa, 1996

Promotion of Access to Information Act 2 of 2000

Promotion of Administrative Justice Act 3 of 2000

International instruments

African Charter on Human and Peoples' Rights (1981)

Convention against Torture and other Cruel, Inhuman or Degrading Treatment or Punishment (1984)

Convention on the Rights of the Child (1989)

European Convention for the Protection of Human Rights and Fundamental Freedoms (1950)

Inter-American Convention on Human Rights (1969) 
International Convention on the Elimination of All Forms of Racial Discrimination (1965)

International Covenant on Civil and Political Rights (1966)

International Covenant on Economic, Social and Cultural Rights (1966)

Protocol to the African Charter on Human and Peoples' Rights on the Rights of Women (2000)

Rome Statute of the International Criminal Court (1998)

United Nations Basic Principles and Guidelines on the Right to a Remedy and Reparations for Victims of Violations of International Human Rights and Humanitarian Law (2005)

United Nations Human Rights Committee Nature of the General Legal Obligation on States Parties to the Covenant (2004)

Universal Declaration of Human Rights (1948)

\section{List of Abbreviations}

CAT

CERD

CRC

HRC

ICC

ICCPR

ICESCR

IRRC

UDHR

Yale LJ
Convention against Torture and Other Cruel, Inhuman or Degrading Treatment or Punishment International Convention on the Elimination of All Forms of Racial Discrimination Convention on the Rights of the Child Human Rights Committee International Criminal Court International Covenant on Civil and Political Rights

International Covenant on Economic, Social and Cultural Rights International Review of the Red Cross Universal Declaration of Human Rights Yale Law Journal 